\title{
Current situation in ARDS in the light of recent studies: Classification, epidemiology and pharmacotherapeutics
}

\author{
Fatma YILDIRIM ${ }^{\mathbf{1}}($ ID) \\ İrem $\operatorname{KARAMAN}^{2}(\mathrm{ID})$ \\ $\operatorname{Akın~KAYA~}^{3}(\mathbb{D D})$
}

Cite this article as: Yıldırım F, Karaman i, Kaya A. COVID-19 and thrombosis: COVID-19 related acute Current situation in ARDS in the light of recent studies: Classification, epidemiology and pharmacotherapeutics. Tuberk Toraks 2021;69(4):535-546.

Address for Correspondence (Yazışma Adresi)

\section{Dr. Fatma YILDIRIM}

Clinic of Pulmonary Medicine,

Intensive Care Unit, University of

Health Sciences Dışkapı Yıldırım

Beyazit Research and Education Hospital,

ANKARA - TURKEY

e-mail: ftagassi@hotmail.com

OCopyright 2021 by Tuberculosis and Thorax.

Available on-line at www.tuberktoraks.org.com
${ }^{1}$ Clinic of Pulmonary Medicine, Intensive Care Unit, University of Health Sciences Dışkapı Yıldırım Beyazıt Research and Education Hospital, Ankara, Turkey

${ }^{1}$ Sağlık Bilimleri Üniversitesi Dışkapı Yıldırım Beyazıt Eğitim ve Araştırma Hastanesi, Göğüs Hastalıkları Kliniği, Yoğun Bakım Ünitesi, Ankara, Türkiye

2 Bahçeşehir University Faculty of Medicine, Intern, Istanbul, Turkey

${ }^{2}$ Bahçeşehir Üniversitesi Tıp Fakültesi, Intern, Istanbul, Türkiye

${ }^{3}$ Department of Pulmonary Medicine, Ankara University Faculty of Medicine, Ankara, Turkey

3 Ankara Üniversitesi Tıp Fakültesi, Gögüs Hastalıkları Anabilim Dalı, Ankara, Türkiye

\begin{abstract}
Current situation in ARDS in the light of recent studies: Classification, epidemiology and pharmacotherapeutics

In the last 50 years, there have been great research and developments in the definition and pathophysiology of acute respiratory distress syndrome (ARDS), the most progressive form of acute hypoxemic respiratory failure. Although there are various discussions and recommendations, the definition of ARDS is still based on the Berlin 2012 diagnostic criteria. Despite various studies in recent years, there is still no effective pharmacotherapeutic agent for the treatment of ARDS. Lung protective mechanical ventilation (low tidal volume, low plateau pressure, low driving pressure) in all ARDS patients, prone position, neuromuscular blockade (cisatracurium) in moderate-severe ARDS patients, and hydrocortisone therapy in sepsis-associated ARDS patients are treatments that contribute to survival. In this review, current changes in the definition and epidemiology of ARDS, recent pharmacotherapeutic research and mesenchymal stem cell therapies will be discussed in the light of newly introduced ARDS phenotypes.
\end{abstract}

Key words: Acute respiratory distress syndrome; phenotypes; pharmacotherapeutic; mesenchymal stem cell therapy 
ÖZ

Güncel çalışmalar ışığında ARDS'de mevcut durum: Sınıflandırma, epidemiyoloji ve farmakoterapötikler

Akut hipoksemik solunum yetmezliğinin en progresif formu olan akut solunum sıkıntısı sendromunun (ARDS) tanımı ve patofizyolojisi konusunda son 50 yılda büyük araştırmalar ve gelişmeler olmuştur. ARDS tanımı halen üzerinde çeşitli tartışma ve öneriler olmasına rağmen Berlin 2012 tanı kriterlerine dayanmaktadır. Son yıllardaki çeşitli araştırmalara rağmen ARDS tedavisinde etkin bir farmakoterapötik ajan halen bulunmamaktadır. Tüm ARDS hastalarında akciğer koruyucu mekanik ventilasyon (düşük tidal volüm, düşük plato basıncı, düşük sürücü basınç); orta-ağır ARDS hastalarında pron pozisyon, nöromüskuler blökor (sisatraküryum) ve sepsis ilişkili ARDS hastalarında hidrokortizon tedavisi sağkalıma fayda sağlayan tedavilerdir. Bu derlemede ARDS tanımındaki ve epidemiyolojisindeki günümüze kadar olan değişiklikler, tedavideki farmakoterapötik son araştırmalar ve mezenkimal kök hücre tedavileri yeni ortaya atılan ARDS fenotipleri eşliğinde tartışılacaktır.

Anahtar kelimeler: Akut solunum sıkıntısı sendromu; fenotipler; farmakoterapötik; mezenkimal kök hücre tedavisi

\section{Current Status in Definition and Classification of ARDS Severity}

Acute respiratory distress syndrome (ARDS) is a progressive form of acute hypoxemic respiratory failure characterized by sudden onset of severe dyspnea and hypoxemia. Patients with ARDS present with diffuse, bilateral infiltrates on lung images [lung radiography or thoracic computed tomography (CT)], and refractory hypoxemia that does not respond to supplemental oxygen therapy. ARDS was first described in 1967 by Asbaugh et al. (1) in 12 patients who developed acute respiratory distress. Since then, there have been many changes in the definition of ARDS. First, in 1988, Murray et al. (2) expanded the definition of ARDS by describing the Adult Respiratory Distress Syndrome, which was described by a lung injury scoring system consisting of 4 parameters (0-4):

1. Degree of hypoxemia [Partial arterial oxygen pressure $\left(\mathrm{PaO}_{2}\right)$ / fraction of inspired oxygen $\left.\left(\mathrm{FIO}_{2}\right)\right]$

2. Static lung compliance,

3. Positive end-expiratory pressure (PEEP) level,

4. Extent of radiological infiltrations. Later, in 1994, at the American-European consensus conference, $\mathrm{PaO}_{2} /$ $\mathrm{FIO}_{2}<300 \mathrm{mmHg}$ was defined as consistent with the acute lung injury (ALI) and $\mathrm{PaO}_{2} / \mathrm{FIO}_{2}<200 \mathrm{mmHg}$ was recognized as ARDS (3). The definition of ARDS, which is still valid today, is based on the diagnostic criteria determined in Berlin definition, 2012 (4). The Berlin definition clarified several question marks raised from the consensus in 1994. First, the concept of 'acute' has been clarified as new onset or worsening respiratory symptoms within 1 week after a known clinical event. Second, it was stated that the underlying etiology for bilateral opacities on chest $\mathrm{X}$-ray or thorax $\mathrm{CT}$ should not be pleural effusion, atelectasis, or nodules. Third, in patients without an obvious risk factor for ARDS, the fact that edema is not due to heart failure or fluid overload should be confirmed with supportive tests such as echocardiography. Fourth, the concept of ALI has replaced by different stages of ARDS: mild ARDS if $\mathrm{PaO}_{2} / \mathrm{FIO}_{2}$ is between 200-300 mmHg under at least $5 \mathrm{~cm} \mathrm{H}_{2} \mathrm{O}$ positive end-expiratory pressure (PEEP); moderate ARDS if $\mathrm{PaO}_{2} / \mathrm{FIO}_{2}$ is between $100-200 \mathrm{mmHg}$; severe ARDS if $\mathrm{PaO}_{2} / \mathrm{FIO}_{2}$ is $<100 \mathrm{mmHg}$. The definition of the Berlin diagnostic criteria was based on the results of a meta-analysis of 4188 patients. In this meta-analysis, mortality was observed as $27 \%$ in mild ARDS, $35 \%$ in moderate ARDS, and up to $45 \%$ in severe ARDS (4). Today, the $\mathrm{PaO}_{2} / \mathrm{FIO}_{2}$ ratio is still the most frequently used parameter in the classification of ARDS patients, determining patients' weight and choosing treatment, and predicting prognosis.

In 2016, the Kigali modification to the Berlin definition brought a different perspective to ARDS in developing countries (5). After Kigali modification, whether $1 / 3$ of ARDS patients do not need mechanical ventilation (MV) and whether the need for PEEP is essential have been widely discussed. In this modification, the timing in the Berlin definition remained the same as 1 week, however, it was stated that the requirement of at least $5 \mathrm{~cm} \mathrm{H}_{2} \mathrm{O}$ PEEP, which is used to determine the weight of the patients, may not be necessary in patients with hypoxemic and bilateral infiltrations. Moreover, in developing countries where arterial blood gas monitoring is not possible, it was reported that peripheral oxygen saturation $\left(\mathrm{SpO}_{2}\right) /$ $\mathrm{FIO}_{2}$ could be used instead of $\mathrm{PaO}_{2} / \mathrm{FIO}_{2}$, and the Sp $\mathrm{O}_{2} / \mathrm{FIO}_{2}$ ratio was determined as 315 . Additionally, Kigali modification supported the use of thoracic ultrasonography to confirm bilateral infiltrations necessary to confirm the diagnostic criteria of ARDS, in addition to chest X-ray and thorax CT (5). 
Today, patients with bilateral infiltrations due to coronavirus disease 2019 (COVID-19) that was caused by severe acute respiratory syndrome coronavirus 2 (SARS-CoV-2) who received high-flow nasal oxygen (HFNO) had similar inflammatory markers and hypoxemia level with ARDS patients in MV. Based on this similarity, it has been stated that a modification can be made in the Berlin definition. Many patients who received HFNO during the pandemic had acute respiratory failure and non-cardiac pulmonary edema. Hence, how will this new definition and classification contribute to clinics? The answer is that ARDS awareness will hopefully increase for this patient group. These patients are candidates for administering ARDS treatments during the early stages of acute respiratory failure. HFNO treatment provides 2-5 $\mathrm{cm} \mathrm{H}_{2} \mathrm{O}$ of PEEP, which can meet the $5 \mathrm{~cm}$ $\mathrm{H}_{2} \mathrm{O}$ requirement that is present in the Berlin diagnostic criteria. From an epidemiological point of view, adding this criterion may enable increased rates of detection of ARDS in the early stages, and a wider application of ARDS diagnosis among the patients with high oxygen demand. For patients treated with HFNO with a flow of at least $30 \mathrm{~L} / \mathrm{min}$; it was stated that the time in the Berlin definition could be extended to 14 days by keeping the oxygenation and radiological findings the same, and the $\mathrm{SpO}_{2} / \mathrm{FIO}_{2}<315$ $\mathrm{mmHg}$ Kigali modification could be used (6).

Today, besides the oxygenation ratio of patients, the degree and extent of consolidation in imaging modalities are used for determining the severity of ARDS. The Radiographic Assessment of Lung Edema (RALE) was developed to evaluate the density and extent of alveolar opacities on chest X-ray. In ARDS patients, the RALE score is ranged between 0-4 for consolidation and 0-3 for opacification for each radiographic quadrant. The sum of the products of these scores from each quadrant gives the RALE score (maximum score $=48$ ). Wallen et al. (7) have compared the lung weights and radiographic images of 72 organ donors (devolution cohort) with radiographic and clinical features of 174 patients (validation cohort) from the ARDSNet study. They have found that in ARDS patients, high RALE scores were strongly correlated with total lung weight $(r=0.59, p<0.001)$, with a high RALE score associated with lower $\mathrm{PaO}_{2} / \mathrm{FIO}_{2}$ and worse survival. Conservative fluid management has provided a significant reduction in the RALE score for 3 days (7).
Since ARDS is a heterogeneous syndrome, clinical methods may be insufficient for the recognition of ARDS, and patients may be underdiagnosed. Bhattarai et al. (8) have conducted a study claiming that machine learning $(\mathrm{ML})$ could be used to understand the heterogeneity of the disease and to develop predictive algorithms. A large database was created from the ventilator waveform analysis. They have stated that phenotype determination based on the ML algorithm without a supervisor may be important in dividing the highly heterogeneous ARDS population into more homogeneous classes. While the results of the study are promising, the lack of generalizability and concerns about the alarm intensity might cause difficulties in adopting these algorithms. In the study of Bhattarai et al., predictive models for ARDS have been created using the electronic health records of hospitals and the existing MIMIC III database and ARDS network studies (9). ML algorithms may contain variables that can be used not only to predict patients who may develop ARDS, but also to predict patients who may develop ARDS.

\section{ARDS Incidence and Epidemiological Studies}

Since the Berlin definition emerged, the largest international cohort study to date on the epidemiology, current incidence, mortality, recognition, management, and outcomes of ARDS patients is The Large Observational Study to Understand the Global Impact of Severe Acute Respiratory Failure (LUNG SAFE). In this study, besides the evaluation of ARDS incidence and outcome, it was aimed to evaluate clinicians' recognition of ARDS according to the Berlin definition, and to evaluate MV practices and the use of assistive methods (such as prone position) in the routine clinical practice. This international, multicenter, prospective cohort study was conducted in 5 continents, 50 countries and 459 intensive care units (ICUs) in both the northern and southern hemisphere. In the northern hemisphere, patients admitted to the ICU between February-March 2014 were included; whereas in the southern hemisphere, patients admitted to the ICU between June-August 2014 were included in the study. Patients who received invasive or non-invasive MV support for four consecutive winter weeks were evaluated daily for possible acute respiratory failure. All researchers were given webbased training to increase the reliability of chest X-ray interpretation. Only $60 \%$ of patients were recognized by clinicians. The recognition rate of ARDS was 
$51.3 \%(95 \% \mathrm{Cl}, 47.5-55.0 \%)$ for mild ARDS and 78.5\% (95\% Cl, 74.8-81.8\%) for severe ARDS. 34\% of clinicians made a diagnosis of ARDS when patients fully met the diagnostic criteria for ARDS $(95 \% \mathrm{Cl}$, 32.0-36.0). The severity of ARDS was detected as mild ARDS $30.0 \%(95 \% \mathrm{Cl}, 28.2-31.9 \%)$, moderate ARDS $46.6 \%(95 \% \mathrm{Cl}, 44.5-48.6 \%)$, and severe ARDS $23.4 \%(95 \% \mathrm{Cl}, 21.7-25.2 \%)(9)$.

Epidemiological studies on ARDS were reviewed in 2018 to evaluate the incidence, risk factors, demographic characteristics of patients, and management strategies and outcomes of ARDS. It was reported that ARDS was seen in $10 \%$ of all patients in the ICU, and in $23 \%$ of all MV patients, reported as 5.5 cases per ICU bed per year (10). Although regional differences exist in the incidence of ARDS, this was not as much as in previous years.

Two large cohort studies on the epidemiology, management and outcomes of ARDS in ICUs in Europe; The SOAP (Sepsis Occurrence in Acutely III Patients) study $(n=3147)$ performed on May 1-15, 2002 and the ICON (Intensive Care over Nations) study $(\mathrm{n}=$ 4601) conducted on May 8-18, 2012 were compared. The diagnosis of ARDS was made according to the Berlin definition in both studies. Tidal volume, PEEP value, plateau pressures, $\mathrm{FIO}_{2}$, and best $\mathrm{PaO}_{2}$ values in every 24 hours, 60-day mortality and duration until hospital discharge were compared between two studies. The prevalence of ARDS at ICU admission $(5.1 \%$ vs $5.0 \% ; p=0.866)$ and the frequency of ARDS in patients who needed MV during ICU admission $(10.4 \%$ vs $10.7 \% ; p=0.793)$ were similar. Within 24 hours of the ARDS diagnosis, the severity of ARDS was classified as following: $29.7 \%$ mild ARDS, 47.3\% moderate ARDS, and 23\% severe ARDS. Tidal volumes, plateau and driving pressures were lower in the ICON study. ICU mortality (41.1\% vs 36.9\%) and hospital mortality (46.2\% vs. $44.4 \%$ ) were similar between two studies. High plateau pressure $(>29 \mathrm{~cm}$ $\left.\mathrm{H}_{2} \mathrm{O}\right)$ and driver pressure $\left(>14 \mathrm{~cm} \mathrm{H}_{2} \mathrm{O}\right)$ on the first day of $\mathrm{MV}$ were independent risk factors for in-hospital mortality, while high tidal volume (TV) $[>8 \mathrm{ml} / \mathrm{kg}$ ideal body weight (IBW)] was not a significant risk factor. The result of the comparison between two studies showed that the frequency of ARDS in ICUs did not change from 2002 to 2012. Low $\mathrm{PaO}_{2} / \mathrm{FIO}_{2}$ ratio, advanced age, high Simplified Acute Physiology Score (SAPS) II, and multi-organ failure were other independent risk factors for ARDS mortality (11).
Although there are many studies conducted on ARDS treatment today, attention is now focused on the prevention of the development of ARDS. The reason for this is that it was seen that most of the patients followed in MV in the ICU are at risk for developing ARDS. Moreover, pulmonary complications are more frequently seen in patients who are at risk of ARDS. Therefore, it is important to diagnose the patient group who is at risk before the development of ARDS, and to optimize their treatment to prevent the progression to severe ARDS. The Lung Injury Prediction Score (LIPS) was developed to identify patients who are at risk for the development of acute lung injury (ALI) earlier. Components of LIPS include high-risk trauma, high-risk surgery, aspiration, shock, pneumonia, pancreatitis, and other factors [alcohol use, hypoalbuminemia, obesity (body mass index $>30 \mathrm{~kg} /$ $\mathrm{m}^{2}$ ), chemotherapy, $\mathrm{FIO}_{2}>0.35$ (> $\left.4 \mathrm{~L} / \mathrm{min}\right)$, oxygen saturation $<95 \%$, acidosis $(\mathrm{pH}<7.35)$, diabetes mellitus]. A LIPS above 4 was associated with increased risk of developing ARDS within an average of 2 days. This scoring system was validated in a multicenter, observational, prospective study by Gajic et al. (2011). In the mentioned study, 5.584 patients who are at risk of ALI were evaluated. ARDS developed in total of 229 (4.1\%) patients with median ALI development was observed as 2 days (interquartile range 1-4) in total of $148(6.8 \%)$ patients. Area under the curve (AUC) was calculated as 0.80 (95\% Cl 0.78-0.82) for LIPS score to distinguish patients who will develop ALI from patients who will not. When corrected for disease severity and predisposing factors, the development of ALI increased the risk of in-hospital death by 4.1 times (12).

To investigate the epidemiological characteristics and outcomes of patients at risk for ARDS in the ICU, "A Practice of Ventilation in Critically III Patients without ARDS at onset of Ventilation (PROVENT)" study was conducted (13). Patients from 119 ICUs in 16 countries were included in this international, multicenter, prospective study between January 2014 and January 2015. LIPS was used to identify risk factors for ARDS. LIPS score $>4$ was defined as increased risk for development of ARDS. While the primary endpoint of the study was to determine the proportion of patients at risk for ARDS, the secondary endpoints were the determination of TV $\left(\mathrm{ml} / \mathrm{kg}\right.$ IBW), PEEP $\left(\mathrm{cm} \mathrm{H}_{2} \mathrm{O}\right)$, pulmonary complications, and clinical outcomes. Among the 935 patients included in the study, 282 (30\%, 95\% Cl 27-33) were at risk for the develop- 
ment of ARDS. This rate corresponds to 0.14 cases per ICU bed per 1 week. The TVs were similar between patients who are at-risk and non-at-risk [median $7.6 \mathrm{ml} / \mathrm{kg}$ (IQR 6.7-9.1) vs $7.9 \mathrm{ml} / \mathrm{kg}$ (IQR 6.8-9.1); $p=0.346$ ], whereas PEEP values were higher in patients who were at risk for ARDS [median $6 \mathrm{~cm}$ $\mathrm{H}_{2} \mathrm{O}$ (IQR 5.0-8.0) vs $5.0 \mathrm{~cm} \mathrm{H}_{2} \mathrm{O}$ (IQR 5.0-7.0); $\mathrm{p}<$ $0.001]$. ARDS prevalence was expectedly found higher among patients at risk [19/260 (7\%) vs $17 / 556$ (3\%); $\mathrm{p}=0.004]$. Hospital mortality (16\% vs $32 \%, \mathrm{p}<$ $0.0001)$, ICU mortality ( $12 \%$ vs $29 \%$; $p<0.0001)$ and 90-day mortality ( $17 \%$ vs $31 \%$; $p<0.0001)$ were higher in patients who were at risk of ARDS (13). The PROVENT-iMIC study, a version of the PROVENT study conducted in developing countries, was conducted in 54 ICUs in 10 Asian countries. In this study evaluating 1.315 patients, the median TV was similar between groups with LIPS $<4$ and $>4$, however, TV was lower in ARDS patients (7.9 [6.8-8.9], 8.0 [6.89.2], and 7.0 [5.8-8.4] mL/kg IBW; $p=0.0001$ ). Median PEEP value was similar between LIPS $<4$ and LIPS $\geq 4$ groups, but higher in ARDS patients (5 [5-7], 5 [5-8], and 10 [5-12] $\mathrm{cm} \mathrm{H}_{2} \mathrm{O} ; \mathrm{p}<0.0001$ ). The proportion of patients with LIPS $\geq 4$ and ARDS was $68 \%$ (95\% Cl: $66-71)$ and 7\% (95\% Cl: 6-8), respectively. Pulmonary complications increased incrementally from patients with LIPS $<4$ to those with LIPS $\geq 4$ $(19 \%, 21 \%$, and $38 \%$, respectively; $p=0.0002)$. Similarly, ICU mortality increased as LIPS increased $(17 \%, 34 \%$, and $45 \%$, respectively; $\mathrm{p}<0.0001)$. In PROVENT-iMIC study, the predictive capacity of LIPS for ARDS development was found low (AUC of receiver operating curve $0.62,95 \% \mathrm{Cl}$ : $0.54-0.70$ ) (14).

\section{ARDS Phenotypes and Their Responses to Pharmacological Treatments}

Recently, ARDS phenotypes are increasingly defined among ARDS cohorts. It is reported that phenotyping in ARDS is important to determine the clinical phenotypes that will respond to specific treatment modalities, and to make better selection of patients for future clinical studies. Sepsis, mainly arising due to pneumonia, is the most important direct cause of ARDS in adult patients. Clinical ARDS categories differ in terms of clinical predictors and biomarker profiles of direct (eg, pneumonia, aspiration, or ischemia-reperfusion injury) or indirect (eg, extrapulmonary sepsis, multiple transfusion, pancreatitis) ARDS in the meaning of mortality factors. However, there is currently insufficient evidence to prove that these clinical categories respond differently to ARDS treatments. In addition to the $\mathrm{PaO}_{2} / \mathrm{FIO}_{2}$ ratio that is used in the physiological classification of ARDS, pulmonary dead space fraction and ventilatory ratio are associated with high mortality in ARDS patients (15). The ventilatory rate is calculated as [minute ventilation $(\mathrm{mL} /$ min $\left.) \times \mathrm{PaCO}_{2}(\mathrm{mmHg})\right] /$ [predicted body weight $\times$ $100 \times$ ideal $\mathrm{PaCO}_{2}(\mathrm{mmHg})\left(\right.$ ideal $\mathrm{PaCO}_{2} 37.5$ $\mathrm{mmHg})]$.

Matthay et al. (16) have classified ARDS patients according to their clinical status, physiological features, and radiological images. Biological phenotypes have been created by investigating the plasma protein markers, gene expression levels and common microbiological pathogens. Additionally, radiological imaging methods can also be used to identify morphological phenotypes in ARDS, and these phenotypes may respond distinctively to different ventilator strategies. Two phenotypes, focal and non-focal ARDS, were defined according to the characteristics of lung infiltrates in thorax CT (17). In non-focal ARDS, patients have diffused alveolar opacities on thorax CT, whereas in focal ARDS, there is focal aeration loss, particularly in the lower lobes and dependent regions. According to observational studies, non-focal ARDS patients have more recruitable lung areas. It has been suggested that these distinctive radiological phenotypes may respond uniquely to different MV strategies. For instance, while it has been hypothesized that non-focal ARDS would benefit from higher PEEP values together with recruitment maneuvers, utilizing lower PEEP values with prone position seems reasonable to prevent overdistension in focal ARDS $(17,18)$. The LIVE study was conducted to test this hypothesis. In this randomized clinical trial, MV adjustments were made by evaluating lung morphology on thorax CT. Personalized ventilation strategies were applied for 420 moderate-severe ARDS patients. Non-focal ARDS patients were given $6 \mathrm{ml} / \mathrm{kg}$ IBW TV, recruitment maneuvers were performed, and higher PEEP was applied, whereas focal ARDS patients were given lower PEEP with $8 \mathrm{ml} / \mathrm{kg}$ IBW TV and prone position was applied. In the intent-to-treat analysis, no difference was found between the groups in terms of 90-day mortality. In the study, $21 \%$ of the patients were incorrectly classified as focal vs non-focal ARDS (19). The result from LIVE study suggests that evaluating ARDS phenotypes with thorax CT would be challenging for the future. 
In recent years, progression has been made in the identification of biomarkers that are useful in diagnosis, follow-up, pathophysiology, and identification of therapeutic targets of ARDS. Biomarker panels have the potential to be used in molecular phenotyping, risk stratification, and monitoring of ARDS, as well as to identify patients at risk of developing ARDS. Two sub-phenotypes of ARDS have been characterized with hypoinflammatory and hyperinflammatory biomarkers. Calfee et al. (20) performed a latent class analysis for patients from two randomized controlled trials. Over 2000 patients were evaluated from 3 independent patient cohorts (from the NHLBI ARDS Network randomized controlled trials database). Two distinct and stable subphenotypes have been observed in ARDS, with one subphenotype comprising $30 \%$ of ARDS patients in all 3 cohorts. In this subphenotype, shock and acidosis were observed in a higher rate with typically increased inflammatory biomarkers and remarkably poor prognosis. It was also observed that the hyper-inflammatory subphenotype responded differently to PEEP and fluid management strategies $(20,21)$. These findings may be useful in identifying subphenotypes of ARDS patients, which might increase the success in ARDS clinical trials and identification of patient groups that will respond well to various pharmacotherapies. To test this notion, simvastatin has been investigated for its potential effect on reducing the pulmonary and systemic inflammatory response in ARDS patients. In the HARP-1 [Hydroxymethylglutaryl-CoA Reductase Inhibition with Simvastatin in Acute Lung Injury to Reduce Pulmonary Dysfunction-1 Study], simvastatin was found to be safe, and it was associated with improvement in organ dysfunctions in the event of ALI (22). Secondary analysis of this phase-2b randomized trial, HARP-2 [Hydroxymethylglutaryl-CoA Reductase Inhibition with Simvastatin in Acute Lung Injury to Reduce Pulmonary Dysfunction-2 Study] was conducted as a multicenter, randomized controlled trial in the United Kingdom and Ireland. In HARP-2 study, simvastatin $80 \mathrm{mg}$ daily was compared with placebo and interleukin-6 (IL-6) and soluble tumor necrosis factor receptor-1 (sTNFr-1) were measured in the patients' serum. In the HARP-2 study, pneumonia was the leading cause $(55 \%)$ of ARDS. The median number of ventilator-free days was 13 , and 28 -day mortality was $24.5 \%$. The hyperinflammatory type, clinically and biologically defined as class 2, was found compatible with the hyperin- flammatory phenotype in previous studies. Compared to the hypoinflammatory (class 1) phenotype, the hyperinflammatory phenotype had higher sTNFr-1 and IL-6 levels, low platelet values, and a higher requirement of vasopressor use. Significant differences were found between hypoinflammatory and hyperinflammatory phenotypes. The hyperinflammatory phenotype had fewer ventilator-free days (median 2 vs 18 days; $p<0.0001$ ), fewer extrapulmonary organ failure-free days (median 15 vs 27 days; $\mathrm{p}<0.0001$ ), and a higher 28 -day mortality (39\% vs. $17 \%$, p < $0.0001)$. The 28 -day and 90 -day mortality was lower in the hyperinflammatory group receiving simvastatin, therefore, the beneficial effect of simvastatin was more pronounced in the hyperinflammatory phenotype. Moreover, the hyperinflammatory or reactive phenotype had higher events of shock, metabolic acidosis and higher mortality (23).

Previous studies have demonstrated that macrolide treatment reduces neutrophil migration and the release of inflammatory mediators (24). In the secondary analysis of the Molecular Diagnosis and Risk Stratification of Sepsis (MARS) study, it has been reported that macrolide treatment affects the prognosis distinctively in different ARDS phenotypes (25). In the analysis of a large, prospective, observational study, patients were classified into two groups: pulmonary vs non-pulmonary ARDS, and phenotype 1 (hypoinflammatory phenotype with low plasma inflammatory marker levels) vs. phenotype 2 (hyper-inflammatory phenotype with high plasma inflammatory markers) according to 20 plasma biomarkers, and two groups were analyzed separately. Among the 873 ARDS patients studied, 158 (18\%) received macrolide therapy. The most frequently used macrolide was erythromycin (97\%). Other macrolides used were azithromycin and clarithromycin. Macrolide treatment was associated with reduced 28 -day mortality in the entire cohort $(22.8 \%$ vs $31.6 \%$ crude odds ratio $0.64 ; p=0.03)$. The decrement in the mortality in non-pulmonary ARDS and phenotype 1 remained significant after the propensity match analysis (25).

Many protein biomarkers have also been investigated for ARDS phenotyping. Type III pro-collagen peptide (PCP-III) is a bronchoalveolar fluid protein, which has been associated with ARDS outcome and mortality. In a study observing 32 patients, the sensitivity of alveolar PCP-III in diagnosing the proliferative stage 
of ARDS was $90 \%$ with $92 \%$ specificity (26). Later, it was investigated whether PCP-III could be a predictor for utilization of corticosteroid treatment in ARDS (27). In a study comparing methylprednisolone (MPZ) and placebo, unresolved ARDS (persistent ARDS or fibroproliferative ARDS) was defined as the persistence of ARDS criteria at the end of the 1 st week after initiation of appropriate treatment directed for the etiology of ARDS. Patients with PCP-III $>9 \mu \mathrm{g} / \mathrm{L}$ was considered as being at the fibroproliferative stage of ARDS and MPZ was given to these patients. It has been hypothesized that persistent ARDS that is characterized by parenchymal cell proliferation, fibroproliferation, and collagen deposition due to ongoing inflammation, causes prolonged MV duration and increased mortality. This study started to include patients on June 15, 2020 and ended on June 15, 2021 (27). The results of this randomized, parallel group study will reveal the effect of PCP-III-guided MPZ use on ventilator-free days, ICU and hospital mortality in ARDS patients, yet have not been disclosed.

\section{Pharmacotherapeutic Approaches According to Phenotypes}

Despite the significant advances observed in the ICU management strategies of ARDS, mortality rate of this heterogeneous disease remains high and research on the different treatment approaches continue to evolve. Potential pharmacotherapeutic treatments mostly target the pathways that cause morphological changes in the pathogenesis of ARDS. In this direction, anti-inflammatory treatments, and pharmacological treatments aimed at improving lung functions by reducing inflammation and alveolar edema and providing capillary stability have been the subject of several studies. The result of the clinical trials that were investigating the effect of $\beta 2$-agonists, statins, surfactants, and keratinocyte growth factor have been not significant. Additionally, studies evaluating the therapeutic effect of monoclonal antibodies (such as anti-TNF and TNFR fusion protein) did not find a significant result. Moreover, it was found that aspirin did not have a protective effect in patients who are at higher risk for the development of ARDS (28).

One of the first investigated anti-inflammatory treatment in ARDS was MPZ. Short-term use of high-dose MPZ in patients at risk of ARDS or in the early stages of ARDS failed to demonstrate reduced mortality (29). Similarly, its utilization in the advanced stages of ARDS was not successful to prove reduced mortality rate $(30,31)$. In a double-blind, randomized controlled, single-center study investigating the use of low-dose hydrocortisone (4x50 mg total $200 \mathrm{mg} /$ day IV) for the first 7 days in patients with sepsis-associated ARDS, a rapid and continuous improvement in pulmonary functions $\left(\mathrm{PaO}_{2} / \mathrm{FIO}_{2}\right.$ ratio and LIPS) was detected after hydrocortisone administration. After adjusting for confounding factors, no significant difference in terms of 28-day mortality was observed between the two groups ( $\mathrm{HR} 0.80,95 \% \mathrm{Cl} 0.46$ $1.41 ; p=0.44)$. In the survival model, the APACHE II score was the most important variable affecting the mortality (HR 0.39; 95\% Cl 0.22-0.69; $\mathrm{p}=0.0011$ ). The mortality rate was lower in patients who received hydrocortisone treatment than patients who did not receive hydrocortisone (HR 0.42; 95\% $\mathrm{Cl} 0.24-0.75$; $\mathrm{p}=0.003$ ) (32). Systemic inflammation in ARDS activates the nuclear factor-Kb (NF-kB) signal system; and NF-kB is downregulated by activated glucocorticosteroid receptor- $\alpha(G R-\alpha)$. In patients with ARDS, endogenously activated GR- $\alpha$ is thought to be insufficient. Therefore, increased pro-inflammatory transcription factor for NF- $\mathrm{KB}$ is observed in circulation and tissues, and its persistently elevated levels in plasma and BAL are correlated with increased inflammation and toxic damage. Insufficient intracellular GR- $\alpha$-mediated anti-inflammatory activation causes critical illness-related corticosteroid insufficiency (CIRCI). Considering $\mathrm{CIRCl}, 1 \mathrm{mg} / \mathrm{kg} /$ day IV MPZ is recommended in the early stages of moderate-severe ARDS $\left(\mathrm{PaO}_{2} / \mathrm{FIO}_{2}<200 \mathrm{mmHg}\right.$, within the first 14 days) (33). However, the Cochrane Review conducted in 2019 reported that there was not sufficient data to claim that corticosteroids reduce mortality in ARDS, thus, the routine use of corticosteroids in ARDS was not recommended (34).

A multicenter, randomized controlled study conducted in 17 different ICUs from training and research hospitals in Spain included moderate-severe ARDS patients $\left(\mathrm{PaO}_{2} / \mathrm{FlO}_{2}<200 \mathrm{mmHg}\right.$, PEEP $\geq 10 \mathrm{~cm}$ $\mathrm{H}_{2} \mathrm{O}, \mathrm{FIO}_{2}>50 \%$ ) within the first 24 hours of ARDS diagnosis. The treatment group $(n=139)$ was given IV $20 \mathrm{mg}$ dexamethasone once a day between days 1 and 5, and then a single dose of $10 \mathrm{mg} I \mathrm{~V}$ dexamethasone between days 6 and 10; while routine ICU follow-up was performed in the control group $(\mathrm{n}=$ 138). The number of days without a ventilator support was higher in the dexamethasone group (group difference 4.8 days, $95 \% \mathrm{Cl} 2.57-7.03 ; \mathrm{p}<0.001$. 
Table 1. Pharmacotherapeutics showing clinical and survival benefit in ARDS phenotypes

\begin{tabular}{|c|c|c|}
\hline Study (year) & Pharmacotherapeutic & Result \\
\hline $\begin{array}{l}\text { Randomized, double-blinded, } \\
\text { placebo-controlled } \\
\text { HARP Study, } 2011 \text { (22) }\end{array}$ & $\begin{array}{l}80 \text { mg Simvastatin vs placebo } \\
\qquad \mathrm{n}=60\end{array}$ & $\begin{array}{l}\text { At day } 7 \text {, there was no difference in extravascular } \\
\text { lung water. } \\
\text { At day } 14 \text {, the simvastatin-treated group had } \\
\text { improvements in non-pulmoner organ dysfunction. } \\
\text { Simvastatin decreased bronchoalveolar lavage IL- } 8 \\
\text { by } 2.5 \text {-fold. } \\
\text { Duration of mechanical ventilation, ICU and } \\
\text { hospital stay and ICU survival were similar. }\end{array}$ \\
\hline $\begin{array}{l}\text { Randomised controlled trial } \\
\text { HARP-2 Study, } 2018 \text { (23) }\end{array}$ & $\begin{array}{l}80 \text { mg Simvastatin vs placebo } \\
\qquad \mathrm{n}=540\end{array}$ & $\begin{array}{c}\text { Hyperinflammatory subphenotype had fewer } \\
\text { ventilator-free days (median } 2 \text { days [IQR } 0-17] \text { vs. } \\
18 \text { [IQR } 0-23] ; p<0.0001) \text {, fewer non-pulmonary } \\
\text { organ failure-free days }(15[0-25] \text { vs. } 27[21-28] ; \\
\mathrm{p}<0.0001) \text {, and higher } 28 \text {-day mortality }(73[39 \%] \\
\text { vs. } 59 \text { [17\%]; } p<0.0001) \text {. } \\
\text { Within the hyperinflammatory subphenotype, } \\
\text { patients treated with simvastatin had significantly } \\
\text { higher 28-day survival than did those given placebo } \\
\qquad(p=0.008) .\end{array}$ \\
\hline $\begin{array}{l}\text { Two centers, prospective } \\
\text { observational study, } 2018 \\
\text { (34) }\end{array}$ & $\begin{array}{l}\text { Erythromycin (97\% used macrolide) } \\
\qquad \mathrm{n}=873\end{array}$ & $\begin{array}{l}\text { Reduced } 30-\text { day mortality in the whole cohort } \\
{[22.8 \% \text { vs. } 31.6 \% \text {; crude odds ratio (OR), } 0.64} \\
\text { (IQR, 0.43-0.96), } \mathrm{p}=0.03] .\end{array}$ \\
\hline $\begin{array}{l}\text { Double-blind, single-center } \\
\text { (Siriraj Hospital, Bangkok), } \\
\text { randomized, placebo- } \\
\text { controlled trial, } 2016 \text { (32) }\end{array}$ & $\begin{array}{l}\text { Hydrocortisone } 50 \text { mg every } 6 \mathrm{~h} \text { or } \\
\text { placebo } \\
\mathrm{n}=197\end{array}$ & $\begin{array}{l}\text { The treatment group had significant improvement in } \\
\text { the } \mathrm{PaO}_{2} / \mathrm{FIO}_{2} \text { and lung injury score }(\mathrm{p}=0.01) . \\
28^{\text {th }} \text { day survival was similar for the whole group } \\
(\mathrm{HR} 0.80,95 \% \mathrm{Cl} 0.46-1.41 ; \mathrm{p}=0.44) \\
\text { Subgroup }(\mathrm{n}=126) \text { with APACHE II score }<25(\mathrm{HR} \\
0.57,95 \% \mathrm{Cl} 0.24-1.36 ; \mathrm{p}=0.20) \text {. }\end{array}$ \\
\hline $\begin{array}{l}\text { Multicenter, randomized } \\
\text { controlled study, } 2017 \text { (37) }\end{array}$ & $\begin{array}{l}\text { Sivelestat vs. standart treatment } \\
\qquad \mathrm{n}=4276\end{array}$ & $\begin{array}{l}\text { Three months was significantly lower in the } \\
\text { sivelestat group compared with the non-sivelestat } \\
\text { group (weighted HR: } 0.83 ; 95 \% \\
\text { Cl: } 0.75-0.93 ; \mathrm{p}<0.002 \text { ). }\end{array}$ \\
\hline
\end{tabular}

Until day 60, 29 (21\%) patients died in the dexamethasone group, whereas 50 (36\%) patients died in the control group (group difference 15.3\%, -25.94.9; $\mathrm{p}=0.0047)$. There was no significant difference between the two groups in terms of adverse events. The most common adverse events were determined as hyperglycemia $(76 \%$ vs. $70 \%$; $>$ > 0.05), new infection in the ICU (pneumonia or sepsis $24 \%$ vs. $25 \%, p>0.05)$ and barotrauma $(10 \%$ vs. $\% 7, p>$ 0.05) (35).

Neutrophil elastase increases vascular permeability and tissue damage in the lung by causing proteolysis. Increased plasma neutrophil elastase levels are proposed to be associated with ARDS severity. It has been thought that neutrophil elastase inhibitors, such as sivelestat, may be effective in the treatment of
ARDS. In the STRIVE study, no difference in mortality was observed between sivelestat and placebo groups (36). In an observational retrospective study conducted by Kido et al. (37) using the Japanese nationwide administrative database, sivelestat was given to 1997 of 4276 patients evaluated in the study. The median use of sivelestat in the first 7 days was 4.8 days, the duration of use during hospitalization was 8.4 days, and the dose of sivelestat was $4.8 \mathrm{mg} / \mathrm{kg} /$ day. After adjusting for modifiers, it was observed that sivelestat group had significantly lower mortality (HR 0.83; 95\% Cl 0.75-0.93; $\mathrm{p}<0.002)$. In the multiple regression analysis, the factors associated with treatment success were younger age ( $<60$ years), absence of a cancer diagnosis, absence of a hemodialysis requirement, and the absence of high-dose MPZ use (37). 
Trials showing positive affect on the clinical (oxygenation, non-pulmoner organ dysfunction, inflammation) outcomes and survival of ARDS patients are very few in number and they summarized in Table 1.

\section{ARDS Pathogenesis and Stem Cell Therapy}

As mentioned in the classification section, ARDS, which is characterized by increased alveolar epithelium and accumulation of alveolar fluid due to increased permeability resulting from endothelial damage, can cause severe lung damage by either directly damaging the lung epithelium or indirectly damaging the vascular endothelium. In the early stage of ARDS, neutrophils and red blood cells migrate to the alveolar area, depending on the severity of lung damage. At this stage, interstitial and alveolar edema can rapidly develop, and hyaline membrane formation begins in the alveolar septa. Alveolar macrophages play a leading role in this inflammatory process. Proteases, reactive oxygen radicals, cytokines, eicosanoids, and phospholipids are released from neutrophils that bind to adhesion molecules in the alveoli or on the endothelial surface. All the aforementioned substances increase the rate of leukocyte migration and inflammatory damage to alveolar and epithelial cells. As a result of this type II epithelial damage, the level of surfactant decreases, and the homeostasis in the fluid transport in the alveoli is impaired, therefore, causing further impairment in the resolution of the alveolar edema. Protein-rich alveolar fluid further impairs surfactant functions, which increases surface tension, causes alveolar collapse, and worsens lung compliance. Endothelial cell damage further increases vascular permeability, and platelets contribute to pulmonary changes. These inflammatory processes together cause ventilation-perfusion mismatch, resulting in impaired oxygenation and carbon dioxide excretion, increased minute ventilation and dead space breathing. The progression of ARDS is characterized by the processes of alveolar epithelial repair and restoration of physiological functions. Many growth factors (such as keratinocyte growth factor) stimulate type II alveolar cells to proliferate and differentiate into type I alveolar cells, and to inhibit apoptosis and increase surfactant production. During the repair processes, alveolar epithelial and endothelial cells regenerate, membrane permeability is restored, and fluid and debris are removed from the alveolar space. In some cases, a failure in the repair phase during the early stages of lung damage cause increased production of collagen, and subsequently, result in the change of the phenotype that cause fibrotic lung damage and poor prognosis. Endothelial stabilization is provided by vascular endothelial cadherin (VE-cadherin), an endothelium-specific adhesion protein in the healthy lung. During lung inflammation, the levels of thrombin, tumor necrosis factor (TNF) and leukocytes increase, causing impaired VE-cadherin adhesion. Neutrophil transmigration via beta-catenin signal pathway stimulates the lung epithelial repair, therefore, may be a potential therapeutic target for ARDS. Active ion transport in the uninjured lung creates an osmotic gradient across the alveolar epithelium, resulting in fluid clearance. In ARDS, this osmotic gradient and alveolar fluid clearance is impaired (38).

Considering its pathogenesis, mesenchymal stromal stem cells (MSCs) have been investigated as a potential cell-based therapy for ARDS. In-vitro MSCs can differentiate into chondrocyte, osteoblast, and adipocyte; however, they do not demonstrate full characteristics of stem cell in vivo. In a model of Escherichia coli endotoxin-induced lung injury, MSCs have reduced pulmonary edema and increased survival in mice (39). MSCs also reduced lung injury in mice and rats, and in ex-vivo human lung models. In another study, MSCs have increased bacterial clearance and provided a survival advantage in the sepsis model (40). Engraftment of MSCs to the site of tissue damage also provides structural support, by secreting proteins with anti-inflammatory properties. Potential therapeutic mechanisms of action of MSCs in ARDS can be listed as following:

1. Secretion of anti-inflammatory proteins [IL-1 receptor antagonist, TNF- $\alpha$ stimulated gene six (TSG6), IGF-1, Lipoxin A4],

2. Modulation of epithelial and endothelial permeability through a paracrine mechanism (Angiopoietin-1, IL-1-ra, Prostaglandin E2),

3. Secretion of proteins that increase alveolar fluid clearance (41). The results of the pre-clinical models led to conduction of phase 1 and phase 2 clinical trials to investigate the effectiveness of MSCs treatment in ARDS (42). Matthay et al. (43) have compared the efficiency of MSC with placebo in moderate-to-severe ARDS patients in a prospective, double-blind, multicenter phase 2a study. Patients with $\mathrm{PaO}_{2} / \mathrm{FIO}_{2}<200 \mathrm{mmHg}$, PEEP $>8 \mathrm{~cm} \mathrm{H} \mathrm{H}_{2} \mathrm{O}$ were randomized as $2: 1$ for $10 \times 10^{6} / \mathrm{kg}$ PBW MSC treatment or placebo group. Patients younger than 18 
years of age, with trauma, with moderate-to-severe hepatic impairment, and who had received cancer treatment in the last 2 years were excluded from the study. From the 1038 patients evaluated from March 2014 to February 9, 2017, 60 patients were included in the study and received MSC infusion. No MSCrelated hemodynamic or respiratory impairment was observed in patients. One patient died due to an unrelated cause within 24 hours of the MSC infusion. There was no difference between the groups in terms of 28 -day mortality $(30 \%$ vs. $15 \%$, odds ratio 2.4 95\% Cl 0.5-15.1). At baseline, the APACHE III score (104 vs 89 ), minute ventilations ( 11.1 vs $9.6 \mathrm{~L} / \mathrm{min})$, and PEEP values (12.4 vs 10.8) of MSC group were higher. The APACHE III adjusted hazard-risk for 28 -day mortality was 1.43 . The MSC viability ranged from $36 \%$ to $85 \%$. Plasma angiopoietin 2 levels were significantly reduced in the MSC group 6 hours after the MSC infusion, which has been attributed to the biological effects of MSC. Angiopoietin 2 is a well-defined mediator and marker of pulmonary and systemic vascular injury (44). In the study of Matthay et al. (43), no difference has been found between the two groups in terms of IL-6, IL-8 and protein C levels.

The results of the phase $1 / 2$ study of MultiStemTM in ARDS patients (NCT02611609) (45), which examined the safety and effectiveness of MSC therapy in the treatment of ARDS, have not yet been announced. MultiStemTM included three cohorts;

Cohort 1: low dose MultiStemTM,

Cohort 2: high dose MultiStemTM,

Cohort 3: the group that will receive either the most reliable and highest MultiStemTM determined from two groups or placebo. This study will be completed after a 1-year follow-up, and the last follow-up report was observed on September 23, 2020 (45). Another study is Mesenchymal Stromal Cells For Acute Respiratory Distress Syndrome (STAT)(NCT 03818854) (46), a phase $2 \mathrm{~b}$, randomized (10 million MSC/kg vs. placebo), double-blind randomized controlled trial, in which a total of 120 patients will be included, and is planned to be completed on July 1, 2023.

In conclusion, although the current fundamental treatment strategies for ARDS, which is still defined with the Berlin 2012 criteria, rely on the lung protective MV strategies and rapid detection and treatment of the underlying etiology of ARDS; research on different pharmacological treatment approaches for ARDS con- tinues to evolve. The potential pharmacological agent to be used in this regard will significantly affect the prognosis according to the ARDS phenotype, therefore, determination of ARDS phenotypes is crucial. Considering the pathogenesis, anti-inflammatory treatments such as corticosteroids, macrolide, simvastatin and sivelestat treatments provide an improvement in the prognosis of specific ARDS phenotypes. Mesenchymal stem cell therapy is a novel ongoing treatment strategy for the repair of the alveolar epithelium and the stabilization of the endothelium. The result of different clinical trials on this subject will clarify the place of MSC in ARDS treatment.

\section{REFERENCES}

1. Ashbaugh DG, Bigelow DB, Petty $T L$, Levine BE. Acute respiratory distress in adults. Lancet 1967; 2(7511): 31923.

2. Murray JF, Matthay MA, Luce JM, Flick MR. An expanded definition of the adult respiratory distress syndrome. Am Rev Respir Dis 1988; 138(3): 720-3.

3. Bernard GR, Artigas A, Brigham KL, Carlet J, Falke K, Hudson L. et al. The American-European consensus conference on ARDS. Definitions, mechanisms, relevant outcomes, and clinical trial coordination. Am J Respir Crit Care Med 1994; 149(3 Pt 1): 818-24.

4. ARDS Definition Task Force, Ranieri VM, Rubenfeld GD, Thompson BT, Ferguson ND, Caldwell E. et al. Acute respiratory distress syndrome: the Berlin Definition. JAMA 2012; 307(23): 2526-33.

5. Riviello ED, Kiviri W, Twagirumugabe T, Mueller A, BannerGoodspeed VM, Officer L. et al. Hospital incidence and outcomes of the acute respiratory distress syndrome using the kigali modification of the Berlin definition. Am J Respir Crit Care Med 2016; 193(1): 52-9.

6. Matthay MA, Thompson BT, Ware LB. The Berlin definition of acute respiratory distress syndrome: Should patients receiving high-flow nasal oxygen be included? Lancet Respir Med 2021; 9(8): 933-6

7. Warren MA, Zhao Z, Koyama T, Bastarache JA, Shaver CM, Semler MW, et al. Severity scoring of lung oedema on the chest radiograph is associated with clinical outcomes in ARDS. Thorax 2018; 73(9): 840-6.

8. Bhattarai S, Gupta A, Ali E, Ali M, Riad M, Adhikari P, et al. Can big data and machine learning improve our understanding of acute respiratory distress syndrome? Cureus 2021; 13(2): e13529.

9. Bellani G, Laffey JG, Pham T, Fan E, Brochard L, Esteban A, et al. Epidemiology, patterns of care, and mortality for patients with acute respiratory distress syndrome in intensive care units in 50 countries. JAMA 2016; 315(8): 788800 . 
10. McNicholas BA, Rooney GM, Laffey JG. Lessons to learn from epidemiologic studies in ARDS. Curr Opin Crit Care 2018; 24(1): 41-48.

11. Sakr Y, François B, Solé-Violan J, Kotfis K, Jaschinski U, Estella $A$, et al. Temporal changes in the epidemiology, management, and outcome from acute respiratory distress syndrome in European intensive care units: a comparison of two large cohorts. Crit Care 2021; 25(1): 87.

12. Gajic O, Dabbagh O, Park PK, Adesanya A, Chang SY, Hou $P$, et al. Early identification of patients at risk of acute lung injury: Evaluation of lung injury prediction score in a multicenter cohort study. Am J Respir Crit Care Med 2011; 183(4): 462-70.

13. Neto AS, Barbas CSV, Simonis FD, Artigas-Raventós A, Canet J, Determann RM, et al. Epidemiological characteristics, practice of ventilation, and clinical outcome in patients at risk of acute respiratory distress syndrome in intensive care units from 16 countries (PROVENT): An international, multicentre, prospective study. Lancet Respir Med 2016; 4(11): 882-93.

14. Pisani L, Algera AG, Neto AS, Ahsan A, Beane A, Chittawatanarat $K$, et al. Epidemiological characteristics, ventilator management, and clinical outcome in patients receiving invasive ventilation in intensive care units from 10 Asian middle-income countries (PRoVENT-iMiC): An international, multicenter, prospective study. Am J Trop Med Hyg 2021; 104(3): 1022-33.

15. Sinha P, Calfee CS, Beitler JR, Soni N, Ho K, Matthay MA, et al. Physiologic analysis and clinical performance of the ventilatory ratio in acute respiratory distress syndrome. Am J Respir Crit Care Med 2019; 199(3): 333-41.

16. Matthay MA, Arabi YM, Siegel ER, Ware LB, Bos LDJ, Sinha $P$, et al. Phenotypes and personalized medicine in the acute respiratory distress syndrome. Intensive Care Med 2020; 46(12): 2136-52.

17. Constantin JM, Grasso S, Chanques G, Aufort S, Futier E, Sebbane $M$, et al. Lung morphology predicts response to recruitment maneuver in patients with acute respiratory distress syndrome. Crit Care Med 2010; 38(4): 1108-17.

18. Reilly JP, Calfee CS, Christie JD. Acute respiratory distress syndrome phenotypes. Semin Respir Crit Care Med 2019; 40(1): 19-30.

19. Constantin MM, Jabaudon M, Lefrant MY, Jaber S, Quenot JP, Langeron $O$, et al. Personalised mechanical ventilation tailored to lung morphology versus low positive end-expiratory pressure for patients with acute respiratory distress syndrome in France (the LIVE study): A multicentre, single-blind, randomised controlled trial. Lancet Respir Med 2019; 7(10): 870-80

20. Calfee CS, Delucchi K, Parsons PE, Thompson BT, Ware $L B$, Matthay MA. Subphenotypes in acute respiratory distress syndrome: Latent class analysis of data from two randomised controlled trials. Lancet Respir Med 2014; 2(8): 611-20.
21. Famous KR, Delucchi K, Ware LB, Kangelaris KN, Liu KD, Thompson $B T$ et al. Acute respiratory distress syndrome subphenotypes respond differently to randomized fluid management strategy. Am J Respir Crit Care Med 2017; 195(3): 331-8.

22. Craig TR, Duffy MJ, Shyamsundar M, McDowell C, O'Kane CM, Elborn JS, et al. A randomized clinical trial of hydroxymethylg/utaryl - coenzyme a reductase inhibition for acute lung injury (The HARP study). Am J Respir Crit Care Med 2011; 183(5): 620-26.

23. Calfee CS, Delucchi KL, Sinha P, Matthay MA, Hackett J, Shankar-Hari M, et al. Acute respiratory distress syndrome subphenotypes and differential response to simvastatin: secondary analysis of a randomised controlled trial. Lancet Respir Med 2018; 6(9): 691-8.

24. Kawashima M, Yatsunami J, Fukuno Y, Nagata $M$, Tominaga $M$, Hayashi S. Inhibitory effects of 14-membered ring macrolide antibiotics on bleomycin-induced acute lung injury. Lung 2002; 180(2): 73-89.

25. Simonis FD, de ludicibus G, Cremer OL, Ong DSY, van der Poll T, Bos LD, et al. Macrolide therapy is associated with reduced mortality in acute respiratory distress syndrome (ARDS) patients. Ann Transl Med 2018; 6(2): 24.

26. Forel JM, Guervilly C, Hraiech S, Voillet F, Thomas G, Somma C, et al. Type III procollagen is a reliable marker of ARDS-associated lung fbroproliferation. Intensive Care Med 2015; 41(1): 1-11.

27. ClinicalTrials.gov. Procollagen-3 Driven Corticosteroids for Persistent Acute Respiratory Distress Syndrome (ProCoCo) (NCT \#03371498) Available from: https://clinicaltrials. gov/

28. Huppert LA, Matthay MA, Ware LB. Pathogenesis of acute respiratory distress syndrome. Semin Respir Crit Care Med 2019; 40(1): 31-9.

29. Silva PL, Pelosi P, Rocco PRM. Personalized pharmacological therapy for ARDS: A light at the end of the tunnel. Expert Opin Investig Drugs 2020; 29(1): 49-61.

30. Bernard GR, Luce JM, Sprung CL, Rinaldo JE, Tate RM, Sibbald WJ, et al. High-dose corticosteroids in patients with the adult respiratory distress syndrome. N Engl I Med 1987; 317(25): 1565-70

31. Steinberg $K P$, Hudson $L D$, Goodman RB. Efficacy and safety of corticosteroids for persistent acute respiratory distress syndrome. N Engl I Med 2006; 354(16): 1671-84.

32. Tongyoo S, Permpikul C, Mongkolpun W, Vattanavanit V, Udompanturak S, Kocak $M$, et al. Hydrocortisone treatment in early sepsis-associated acute respiratory distress syndrome: Results of a randomized controlled trial. Crit Care 2016; 20(1): 329. 
33. Annane $D$, Pastores $S M$, Rochwerg B, Arlt W, Balk RA, Beishuizen $A$, et al. Guidelines for the diagnosis and management of critical illness-related corticosteroid insufficiency (CIRCI) in critically ill patients (Part I): Society of Critical Care Medicine (SCCM) and European Society of Intensive Care Medicine (ESICM) 2017. Intensive Care Med 2017; 43(12): 1751-63.

34. Lewis SR, Pritchard MW, Thomas CM, Smith AF. Pharmacological agents for adults with acute respiratory distress syndrome. Cochrane Database Syst Rev 2019; 7(7):CD004477.

35. Villar J, Ferrando C, Martínez D, Ambrós A, Muñoz T, Soler $J A$, et al; Dexamethasone in ARDS Network. Dexamethasone treatment for the acute respiratory distress syndrome: a multicentre, randomised controlled trial. Lancet Respir Med 2020; 8(3): 267-76.

36. Zeiher BG, Artigas A, Vincent IL, Dmitrienko A, Jackson K, Thompson BT, et al. Neutrophil elastase inhibition in acute lung injury: Results of the STRIVE study. Crit Care Med 2004; 32(8): 1695-702.

37. Kido T, Muramatsu K, Yatera K, Asakawa T, Otsubo H, Kubo T, et al. Efficacy of early sivelestat administration on acute lung injury and acute respiratory distress syndrome. Respirology 2017; 22(4): 708-13.

38. Matthay MA, Zemans RL, Zimmerman GA, Arabi YM, Beitler JR, Mercat $A$, et al. Acute respiratory distress syndrome. Nat Rev Dis Primers 2019; 5(1): 18.

39. Lee JW, Fang X, Gupta N, Serikov V, Matthay MA. Allogeneic human mesenchymal stem cells for treatment of E. coli endotoxin-induced acute lung injury in the ex vivo perfused human lung. Proc Natl Acad Sci USA 2009; 106(38): 16357-62.
40. Lee JW, Krasnodembskaya A, McKenna DH, Song $Y$, Abbott J, Matthay MA. Therapeutic effects of human mesenchymal stem cells in ex vivo human lungs injured with live bacteria. Am J Respir Crit Care Med 2013; 187(7): 751-60.

41. Laffey JG, Matthay MA. Fifty years of research in ARDS. Cell-based therapy for acute respiratory distress syndrome. Biology and potential therapeutic value. Am J Respir Crit Care Med 2017; 196(3): 266-73.

42. Liu KD, Wilson JG, Zhuo H, Caballero L, McMillan ML, Fang $X$, et al. Design and implementation of the START (STem cells for ARDS Treatment) trial, a phase 1/2 trial of human mesenchymal stem/stromal cells for the treatment of moderate-severe acute respiratory distress syndrome. Ann Intensive Care 2014; 4: 22.

43. Matthay MA, Calfee CS, Zhuo H, Thompson BT, Wilson JG, Levitt JE, et al. Treatment with allogeneic mesenchymal stromal cells for moderate to severe acute respiratory distress syndrome (START study): A randomised phase 2a safety trial. Lancet Respir Med 2019; 7(2): 154-162.

44. Parikh SM. Angiopoietins and Tie2 in vascular inflammation. Curr Opin Hematol 2017; 24(5): 432-8.

45. ClinicalTrials.gov. A Phase $1 / 2$ Study to Assess MultiStem ${ }^{\circledast}$ Therapy in Acute Respiratory Distress Syndrome (MUSTARDS) (NCT\#02611609). Available from: https://clinicaltrials.gov/

46. ClinicalTrials.gov. Mesenchymal Stromal Cells For Acute Respiratory Distress Syndrome (STAT)(NCT\#03818854). Available from: https://clinicaltrials.gov/ 